\title{
Chemmeen Processed for Export: The Earliest Signs of Globalisation of the Word?
}

\begin{abstract}
This paper attempts to analyse an English translation of Chemmeen, the Malayalam novel by Thakazhi Shivashankar pillai. Chemmeen has been translated into English by V.K Narayana Menon. A.J Thomas in this article examines Chemmeen as a piece of translation in a globalised world. Originating in Malayalam, the novel was an astonishing success in the world of translation. The article analyses the difficulties, delicacies and the indeterminacies of the translator in maintaining the authorial intention without any alterations. It articulates the strategies, the colonial or imperial and post-colonial impact on the translator in making the work of art a "bestseller." The defence the translator mounts in omitting certain key passages and more importantly the deviation that the translated novel takes from the original seem to stem from the power equation between the two languages.
\end{abstract}

A.J.Thomas

Thakazhi Sivasankara Pillai's (Malayalam) novel Chemmeen, accepted as part of the UNESCO Collection of Representative Works - Indian Series, was translated by V.K.Narayana Menon, and published by Victor Gollancz, London in 1962. It was the first significant Malayalam novel to be translated into English after Independence or, rather, during the early postcolonial era. I have selected Chemmeen for detailed analysis for two reasons: One, this is the first Malayalam novel that captured the imagination of the rest of the world. Therefore the mechanics of its

Translation Today Vol. 2 No. 2 Oct. 2005 @ CIIL 2005 
translation, and its standing vis-à-vis the original, the points of departure it showed from the source text, the way linguistic and cultural problems were handled and resolved and so on would be of great interest. Two, this is the path-breaking novel in translation that showed the way for many more similar success stories. Most of the translation strategies adopted in it - including both the approach which was most faithful to the source text and selective omissions/deletions, compressions, paraphrasing, dilutions and so on - were also adopted by subsequent translators. To interrogate the instances of free translation, the usurpation of authorial authority, and other strategies which result in the appropriation of a work by hegemonic cultures, especially in the back-drop of the attempts at globalising culture that we are witnessing today, we have to understand the processes that were at work in the translation of this pioneering text.

The politics of translation and the peculiar approaches towards culture in the then Third World, emerging in Shanta Rama Rau's "Introduction" to the translation, merit discussion.

Shanta Rama Rau writes that it was our duty in those days (of colonialism) to understand the West and our colonial rulers, but not necessarily vice versa. One's acquaintance with one's own culture would remain really slender too. Writing in English gives the writer a pan-Indian reach and that too among the consumer segments that would actually buy a book! Only very few regional language writers have ever reached the sales figures a successful Indian English writer has reached. Therefore, the idea of a "best-seller" in India is a strange and wonderful thing and Thakazhi Sivasankara Pillai's Chemmeen in English translation became precisely that. In Narayana Menon's brilliant translation, his work got the international audience which it deserved. Shanta Rama Rau's arguments in her introduction to the translation are really revealing in the context of today's market-driven literary products. 
In Chemmeen, Thakazhi made a departure from his avowed commitment to realism as it appeared in his works -- till then -- he brought in a fresh breeze of lyricism and romanticism. The novel acquires the quality of a fable in which life in the fishermen's community is depicted with great emotional detail. The customs, taboos, beliefs, rituals and the day-to-day business of living through the pain of stark existence come alive magically through Thakazhi's pen.

Narayana Menon's translation remains very popular even to this day. It has gone into several editions and is readily available at bookshops all over India.

With Chemmeen, a new era in the history of translation in modern Malayalam fiction was ushered in. The book, in its 1962 UNESCO-sponsored edition, sold 20,000 copies (according to Meenakshi Mukherjee 1972) and created publishing history.

As already averred, Chemmeen is the first significant work of modern Malaylalam fiction translated into English after Independence. It is interesting to note how the approaches to translation, which hitherto conformed to the imperial power's requirements, have changed in the early post-colonial period -- in the selection of equivalents, in the manner of retaining culture-specific items, in the selection of the language, and of course, with the confidence of presenting it to the world something patently Indian. And yet, an eagerness to reach out, bordering on a motivated approach in promoting a product, is visible in the 'presentation' of the translated text of Chemmeen.

The systematic omission of whole sections and passages found in the original tempt one to question Narayana Menon's intentions in doing so. For, these omissions do not appear to be the result of oversight. There is certainly some design, some definite 
pattern underlying these deletions. Was it selective editing as suggested by some foreign editor through the UNESCO connection is a question one is tempted to ask. At any rate, one is led to suspect that Narayana Menon has consciously made the omissions, or acquiesced with an editor's intervention, with an eye targeting language sensibilities. The portions that are left out are, none of them, insignificant or superfluous. They certainly contribute substantially to create Thakazhi's lyrical narrative style in the original. One is led to surmise that editing the exuberantly romantic and lyrical elements in the narrative language of the original is clearly with a view to conform the sensibilities of a western readership that appreciates a terse, subdued, narrative style.

I am citing below a few examples, and am trying to illustrate this with my own translations of the deleted portions:

(1) After the last paragraph on page 14 of the UNESCO Edition that ends with the line, "He must not sing in her vicinity," an entire paragraph has been omitted in the TL Text. I am translating this paragraph thus:

Till two days ago, she flitted about animatedly like a butterfly. The changes that have come over her within these two days! She got things to sit down and think about. She began to understand herself more and more. Isn't it something that adds gravity to life? She is being careful about herself. She must put each step forward cautiously. How can she then dash about as before? A man looked at her breast. That moment she became a woman.

This section is an integral part of the novel that gives a factual picture of a teenage girl in a coastal village of Kerala, who has suddenly become aware what male eyes can do to her selfimage. This may not mean anything to a reader who is used to 
exposed female bodies in the acts of swimming, sunbathing or scanty dressing during summer, or to those who live in societies in which boys and girls are entirely on their own from the time they reach their teens, and have an open approach to love and sex as normal outward expressions of their individuality. One suspects that this portion was deleted because it would not make sense to the target language readers. In other words, the translator was making the novel palatable to the target language readership, in this case, the global reader. But the fact remains that the cultural ethos of the source language society has been sadly, and culpably, compromised before the target language reader, who, one hopes, would be only too happy to apply their imaginative faculties and meet halfway the culture-specificities of the source language community.

(2) Another instance of deletion makes this point even clearer:

On page 49 , towards the middle, a considerable portion of the original has been deleted, which is given below in my translation:

Whatever Chakki said was right. And she was right manner. But those words seemed to rip through Karuthamma's heart.

Walking some distance, Karuthamma looked back. Not wittingly; she cannot help looking back like that. As they reached home, that heart-piercing song began from the seashore.

Said Chakki: "Isn't that boy going to sleep today?"

Again, Chakki spoke, aiming at Karuthamma. "Somehow, you will have to be sent away from this seaside now."

There is an accusation implied in her mother's words. Her presence has brought trouble there; everyone has lost peace of mind. Unable to bear her sorrow and anger, Karuthamma said: 


\section{"What did I do?" \\ Chakki didn't say a word.}

When one considers the fact that there are 146 instances of such deletions and distortions throughout the novel (not given here for reasons of space), the gravity of the situation is brought home.

I am compelled here to observe that thus when one analyzes the text in depth and in detail, comparing it with the original, one finds that the target language (English) text of Chemmeen made available to the world is a highly manipulated, edited, doctored one. Making the translation eminently readable and racy, Narayana Menon got away with it -- at the cost of the narrative marvel of the original, through deletions, suppressions, and mutilations, as proved by the hard evidence of the cases of omission and manipulative translation, illustrated by my alternative translations provided in all these 146 cases.

Looking at it from the point of view of power inherent in the act of translation, which is often described as an act of subversion, we get to one of the main forces at work in the instant case. This is something which has been happening all the time. The translation of Milan Kundera's The Joke is another case in point. It is as if the translator decides to unsettle the supremacy of the original text and literally dismantles it to create the target language text, and adopt several strategies to get around the author. Most of the translators get away with what they do and any number of translators can be found engaged in free translation, subverting authorial power. The translator places herself/himself in a position of authority to decide what the target language reader should read. There is the possibility that the translator may suppress, eliminate partially or misrepresent the source language text in a number of ways. In Chemmeen's case all these seem to have worked; and it also appears that the author was privy to what was happening, unlike in Kundera's case. Writing 
as early as in 1981, Sujit Mukherjee was one of the first to observe a peculiar situation vis-à-vis the regional language writer and his/her English translator. Says Mukherjee:

English pays to a fellow Indian who is confident. An instance of "Whatever be the rights or wrongs of an author's attitude towards his translators, Indo-English literature contains a situation where the translator's superior knowledge of English persuades him to take liberties which the Indian language author allows out of the usual deference that the Indian who is not confident of his own the translator practically usurping the author happened with the English version of Chemmeen." (Mukherjee 1994)

However, further in the essay, Mukherjee says: "Narayana Menon, it is said, was in touch with Thakazhi while the work was in progress (ibid: 29)," giving one the impression that the liberties the translator took was with the knowledge and consent of the author. As quoted by Mukherjee, it was K.Ayyappa Paniker who revealed in an essay that,

"It is not just a literal translation of all that Thakazhi has written. Menon has done a remarkable work of editing....There are numerous other places where the translator, like a good editor, has used his scissors and hacksaw and improved upon the original. On a rough estimate, I have found that about one-fourth of the original has been left out (Paniker 1976)".

Neither in the Introduction nor in the Translator's Note do we find any mention of the deletions. On the other hand, in the Jaico Paperback edition, we find the declaration, "Complete and Unabridged." 
One is led to infer two things here: either Thakazhi was not a good enough writer in Malayalam, he needed to be improved by the translator who was very good at English, and did so with the consent of the author, because the author never made any complaints; or, someone decided that what Thakazhi wrote was not to the reach of English readership (read 'western readers') and that it had to be improved upon to suit their tastes. In short, it was either a kind of exercise in subtle marketing, or a case of an Indian writer and translator being beholden to a hegemonic culture or power structure, and 'adjusting' according to the unwritten diktats of what was considered culturally 'right', or both. Sujit Mukherjee observes:

"The editing while translating was aimed at 'improving' the work, but the translator was surely conditioned by the fact that the translation was prepared for a western audience." Here he adds a note, a kind of raised eyebrow: "For some reason, it required an introduction by Shanta Rama Rau from which we learn that her mother used to lull her to sleep as a child 'with long recitations from Shakespeare or (even more soporific) Tennyson.' Shanta Rama Rau, with a good deal of self-deprecatory rhetoric, was trying to impress the reader that her own country's 'famous literature' was not considered good enough and was not taught in 'good schools.' But in spite of her patriotic exercise, Sujit Mukherjee seems to tell us that he has seen through her game of name-dropping, in her attempt to "sell" the book to the West! Obviously, there was an attempt to create a "best-seller" as she stresses in her introduction. This is probably the first attempt, albeit unawares, at trans-national sale of a Malayalam 'literary product.' Isn't this the precursor to the 'globalised word,' shorn of all local specificities and cultural 'rootedness' and palatable to anyone, anywhere in the world? 
Another force at work in this case is that of cultural appropriation by the hegemonic culture. However, it is so complex that it demands consideration from several angles.

The post-colonial experience is the one fought with the passion to assert the nation's identity, seen in the last half-century. It also involves earnest attempts to show to the rest of the world that we are not existing but living. In Chemmeen, Shanta Rama Rau's Introduction asserts this. Susan Bassnett and Harish Trivedi say that

"it is an understandable urge for simple self-assertion which in a large measure accounts for the great translation boom currently on in India in which any number of Indians have taken it upon themselves to translate works of Indian literature, both ancient and modern, into English, to show the world (including anglophone Indians) that such works do exist." (Bassnett and Trivedi 1999:11-12)

Beginning with the "pride" the people of each linguistic state of the Indian Union, takes their own language and literature, which ends in language chauvinism, at times even virulent and violent, and crowns it all with the obsession of creating a "national language and literature," Indian post-colonialist vis-à-vis language and literature is an emotional subject. Yet, we have opened ourselves to the opportunities offered in the lands of the erstwhile colonisers, and the neo-colonisers (as the so-called masters of globalisation can be described) who are dazzled by their success and material riches. This has given birth to an ambivalent attitude towards the English language - at once one of hatred, being the language of the colonial masters and then of admiration, as the language of power in today's world ensuring success. The professionally patriotic middle-class young men religiously speak and write Hindi, or the regional language, at the same time watch with envy and also desire the lifestyle of the successful city-boy who has empowered himself with the English language. English, for Indians, has long ceased to be the language of the ex-colonisers; it is a language that went far beyond the pale of Anglo-Saxon ascendancy and has ushered in the age of 
the unipolar world. Globalisation has practically become a puppet in the hands of masters and bookmakers who control the play to their target. Free market becomes a free-play of market forces among unequal partners, the most powerful among them calling the shots. The advent of the Internet brought with it, its own hegemony, English being re-consecrated as the international lingua franca, which empowers the individual. The tyranny of English is already there on the scene; the number of people taking crash-courses in the language is increasing day by day. Translation of regional language literatures into English, in this context, resembles the meticulous cleaning, airtight packing and exporting of super-quality cashew or prawn. The hegemonic culture will get hold of all the best things from all parts of the world as Americans proudly tell any visitor to the States. Our colonial past has provided us a ready processing and packaging centre; with our English and our quality-consciousness we certainly have a way ahead. Exporting our cultural items as commodities, or finished cultural products is a blunder happening before our eyes, be it in the form of Kathakali, Kalari or Theyyam (recently there was a news item about Theyyam making a hit in the US). Most of us have taken it as the status of success being achieved. This longing for ranking and recognition abroad is seen all the more in the field of literature, especially fiction. In the wave of the recent boom of Indian English novels, engendered by some authors drawing huge advances from multinational publishers, there are thousands of aspiring hot cake writers ready with their manuscripts, knocking the doors of multi-national publishing houses. The aspiration that Shanta Rama Rau has spelt out in her introduction to the translation of Chemmeen, of creating a "bestseller", has caught on in course of time. Regional writers of creative fiction who get their works translated competently with necessary editing and pruning and get them published by one of these publishers are also falling in line in this queue, often using the guise of the good old ideal of "Universalism." One observes that the 
beginnings of these trends can be traced to the translation of Chemmeen.

Looking at the scene of literary translation into English after Independence, one finds that translation is heavily biased in favour of the hegemonic language. Hence, the need to strike a balance is evident.

Appropriation of our literature as an exotic cultural product by the hegemonic western culture is placed in perspective in this backdrop. Cultural appropriation in the literary front becomes easy when we are ready to offer free translations to suit international taste-buds; and the difficulties in the form of linguistic and cultural specificities has to be peeled out or removed altogether! All those elements that constituted the resistance to a hegemonic culture have to be done away with, completing the act of homogenization of the text. This is what we find in the case of Chemmeen.

This programme began in this country very early during the colonial times, along with the plundering of the riches. The colonisers translated some of the important texts found in the colony for a number of reasons that were mainly extra-literary, like ethnographical, anthropological, and most important of all, for administrative purposes, as Tejaswini Niranjana points out in her book Siting Translation, or as is explicitly stated in Dumergue's "Translator's Note" in his translation of Indulekha. Almost all such translators believed in the superiority of their own language, and most of them thought that the literatures they translated formed the crude. The traces of the continuation of this process are discernible in the instant case as well, in the form of the urge to conform to the tastes of the hegemonic power.

Thakazhi's voice was eliminated through the alteration brought about in the narrative pattern, by systematic deletion of typical passages of the author's exuberant style -- repetitive and explicatory 
narration -- as opposed to the implied, subdued narrative style of the West, attempted by Narayana Menon. If it was poetry that was translated, no one would let off the translator. Since Chemmeen was fiction, it was looked as a 'cultural product', a means of entertainment, to be packaged in the most attractive way. The omissions and commissions by the translator have escaped largely unnoticed and uncommented.

Attempts to exoticise the text, by repeated reference to 'bare breasts' in the translated text - apart from the cover illustration showing a young girl standing topless and a similar line-drawing inside showing a girl with a fish-basket on her head, in the Jaico edition - are strikingly obvious. Thakazhi never mentions in the novel that the fisherwomen went bare-breasted. He didn't use the word mula which is the Malayalam equivalent of the English word breast. He used 'maaru' or 'maaridam', the equivalent translation of which would be 'bosom', which in no way implies 'bare breasts'. By recurrent use of the locution 'bare breasts' of standard erotica, the translator has mispresented the circumspection shown in the original by the use of the equivalent Malayalam word for 'bosom'. And ironically, as established illustratively above, the local cultural specificities have been planed out through deletions.

A new, complete and unabridged version of Chemmeen is needed now, incorporating all that Thakazhi wrote. Let the deleted portions stand and speak independently. The translator should follow a policy of not italicizing culture-specific or locale specific terms and must try to retain as much of the voice of the original author, as possible. There is a clear demand for such a retranslation of Chemmeen, in the changed scenario. The translation with an introductory study can be used as a case study in Translation Studies, or as a text in Indian Writing in English Translation. The present writer has embarked upon such a mission. 


\section{REFERENCES}

Bassnett, Susan and Harish Trivedi (1999) Introduction: of Colonies, Cannibals and Vernaculars in Bassnett, Susan, and H.Trivedi (Eds) Post-colonial Translation: Theory and Practice, London and New York: Routledge.

Devasia, Anitha and Susie Tharu (1997) Englishing Indulekha: Translation, the Novel and History in Prafulla C.Kar (Ed)

Critical Theory: Western and Indian. Delhi: Pencraft.

Kuhiwczak, Piotr (1990) Translation as Appropriation: The case of Milan Kundera's 'The Joke in Bassnett, Susan and Andre Lefevere (eds) Translation, History \& Culture. London and New York: Pinter Publishers.

Kundera, Milan (1993) Author's Note. The Joke. (Fifth version). New Delhi: Rupa \& Co, vii-xi.

Miller, J.Hillis Budick, Sanford and, Wolfgang Iser, (1996), (Eds), The Translatabililty of Cultures. Stanford: Stanford University Press.

Mukherjee, Sujit (1994) The Making of Indo-English Literature in Translation as Discovery. Hyderabad: Orient Longman.

Niranjana, Tejaswini (1992) Siting Translation. California: University of Berkeley Press.

Paniker, K.Ayyappa (1976) The Chemmeen Myth [Literary Criterion XII].

Satchidanandan, K (1999) The State of Translation Indian Literature: Positions and Propositions. New Delhi: Pencraft.

Thakahi Sivasankara Pillai (1956) Chemmeen Kottayam: D.C.Books (1995), (1962) Chemmeen (Trans) Narayana Menon. London: Victor Gollsncz, and New York: Harper and Sons. 
